\title{
DESIGN OF ESCALATORS AND FOLLOWING SAFETY MEASURES
}

\author{
Dragan Živanić ${ }^{1}$, Nikola Ilanković ${ }^{1}$, Atila Zelić ${ }^{1}$, Mirko Katona ${ }^{1}$, \\ Kristina Jakimovska ${ }^{2}$, Anita Vasileva ${ }^{2}$ \\ ${ }^{1}$ Faculty of Technical Sciences, University of Novi Sad, \\ Trg Dositeja Obradovića 6, 21000 Novi Sad, Republic of Serbia \\ ${ }^{2}$ Faculty of Mechanical Engineering, "Ss. Cyril and Methodius"University in Skopje, \\ P.O. Box 464, MK-1001Skopje, Republic of North Macedonia \\ ilankovic@uns.ac.rs
}

\begin{abstract}
A b s t r a c t: Transport of people in buildings and at relatively short distances is possible by escalators. Escalators have a great application in the transport of the people and they represent an important part of vertical transport. As escalators are used at all ages, it is necessary to design them to be safe. Due to the large number of moving parts and the complicated construction of the escalator, it is necessary to perform periodic checks and controls of their correctness and safety for the transport of people. The paper gives an overview of the basic elements of escalators, and some potential dangers and appropriate safety measures for their prevention.
\end{abstract}

Key words: escalators, safety elements, design.

\section{КОНСТРУКЦИЈА НА ЕСКАЛАТОРИ И СООДВЕТНИ БЕЗБЕДНОСНИ МЕРКИ}

А п с т р а к т: Превозот на луѓе во згради и на релативно мали растојанија е можен со употреба на ескалатори. Ескалаторите имаат голема примена во транспортирањето на луѓето и претставуваат важен дел во вертикалниот транспорт. Поради нивната сѐ поголема употреба во различни објекти, неоходно е да се обрне големо внимание на безбедноста при нивно користење. Големиот број на подвижни делови и комплицираната конструкција на ескалаторите, како и фактот дека се користат за превоз на луѓе, наметнува потреба од периоднични проверки и контроли на нивната исправност и нивото на безбедност за превоз на луѓе. Во трудот е даден преглед на основните елементи на ескалаторите, наведени се и некои потенцијални опасности и соодветни мерки за безбедност и превенција.

Клучни зборови: ескалатори; безбедносни елементи; конструирање

\section{INTRODUCTION}

A successful solution for the mass transport of passengers at the metro, railway stations, airports, department stores and similar facilities is achieved only through escalators. Escalators are placed in appropriate places, which are selected so that passengers can be transferred to certain locations as soon as possible.

Escalators are used around the world in places where the use of elevators would be impractical. If used outdoors, they should be protected from rain and other weather conditions. Non-functional escalators can be used as ordinary steps. For people who move and see normally, the use of escalators is completely safe. However, persons who are immobile or tied to wheelchairs cannot use them. Blind people or the elderly with poor eyesight have difficulty entering and exiting escalators, so it is not recommended to use them without an escort. Taking baby prams on an escalator can be perilous. Hence, often the use of prams on escalators is forbidden and the use of elevators instead in highly preferred. 
Escalators consist of the following components: entry-exit platform, supporting structures, stairways, steps, handrails, balustrades, drive system, lubrication systems and safety devices [1]. The basic elements of escalators are shown in more detail in Figure 1.

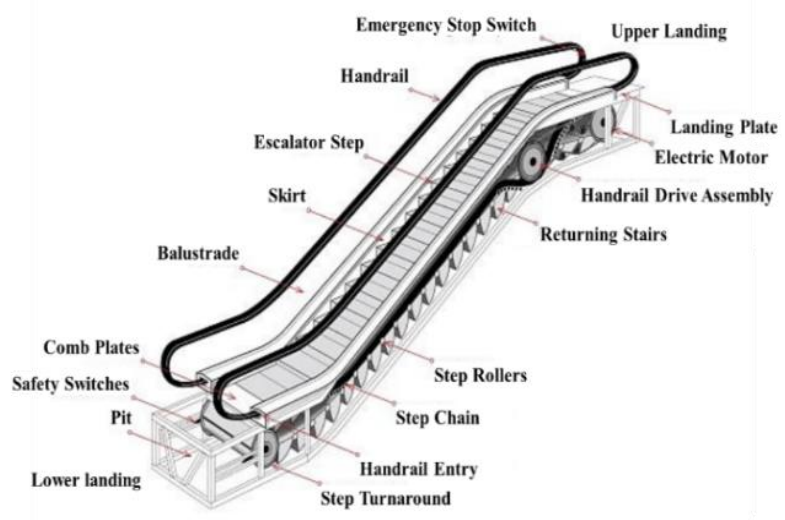

Fig. 1. Escalator elements

\section{ESCALATOR CONSTRUCTION}

Entrance-exit platforms contain parts for turning the steps and drive electric motor and gearbox that drives the stairs. The upper landing platform contains the drive and a main gearbox, while the lower landing platform contains a tensioning mechanism for the drive chain. These sections also contain the ends of the supporting structure.

In addition to platforms, floorboards and combs are added. Floor plates allow easier access to the stairs. This plate is located in the floor plane. A plate with a comb is located between the stationary floor plate and the escalator. It was named like that because the edges have wedges that look like the teeth of a comb.

The teeth of the comb fit into the grooves on stairs. This design reduces the distance between the stairs and the stationary floor plate, which allows easier exit or entry, and also prevents various objects from getting stuck.

The step is the part where people stand during transport. There must be no height difference between the steps higher than $0.24 \mathrm{~m}$.

When the escalators are stopped, they can be used as an auxiliary exit, and then the height between steps must not exceed $0.21 \mathrm{~m}$. The width of the steps must be at least $0.38 \mathrm{~m}$, and nominal length steps must not be less than $0.58 \mathrm{~m}$ nor greater than $1.1 \mathrm{~m}$. Basic step components can be seen in Figure 2.

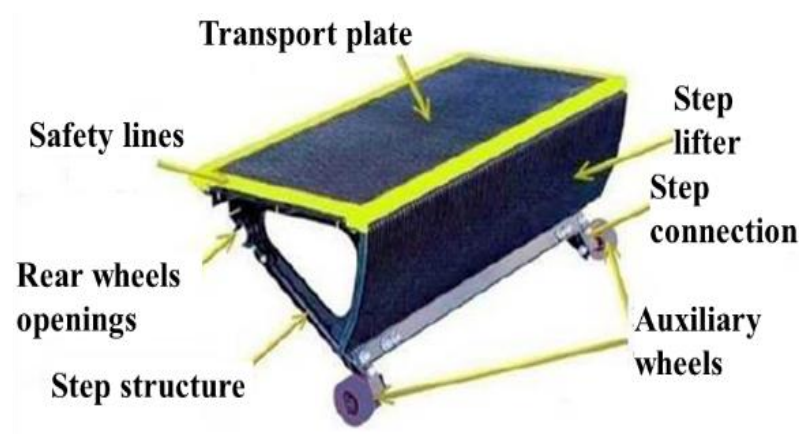

Fig. 2. Step components

Wheels of the step are divided into primary ones, which are located on the axis or semi-axis of the structure of steps and auxiliary, which are located on the axis or semi-axis at the end of the structure.

The primary wheels receive the load from the part of the weight of the step, from the total weight of drive chains, part of passenger weight and radial load due to the action of forces in the drive chains on the convex curvilinear parts of the guides. Auxiliary wheels receive only part of the weight of the steps and passengers.

The supporting structure is made of hollow profiles connecting the upper and lower entranceexit platform. It consists of from two lateral sides connected with transverse elements from the lower side of the structure. The ends are connected to the entrance and exit platforms by means of steel or concrete girders.

The handrail is an infinite, movable, smooth belt, which serves to hold and relying for people when using escalators. The handrail is placed on the upper side of the balustrade and moves in the same direction and at the same speed as the escalator. The speed of the handrail is allowed to differ by $2 \%$ from the speed of the steps. The balustrade represents the stair railing.

The drive system of escalators consists of 3 main subsystems:

- main driving electric motor and gearbox;

- step drive system;

- handrail drive system.

Variations in the placement of these systems depend of which type of escalator is in question.

Escalators have an automatic lubrication system, which allows the oil for lubrication to reach the main drive chain, the drive chain of steps and the drive chain of handrails. Oil flow can be regulated by setting a time controller which controls time periods for lubrication and automatically turns the flow on and off. 
Escalators must be equipped with a variety of devices that will automatically stop the movement of escalators in an emergency. When a sudden stop occurs, the escalator must not be restarted until the problem has been detected and rectified. If one of the safety devices does not react as it should, another additional device will be activated automatically, which will activate an electrical fuse that interrupts the power supply to the drive EM, which automatically stops the escalator. Basic safety measures are given in [2].

\section{INJURY STATISTICS}

The following figures graphically show various statistics of injuries due to accidents on escalators. Thus, Figure 3 shows the percentages of age groups, in men and women, who were hospitalized due to injuries on the escalator.

Figure 4 shows the distribution of risk factors that were the causes of accidents on escalators, and Figure 5 shows injured body parts.

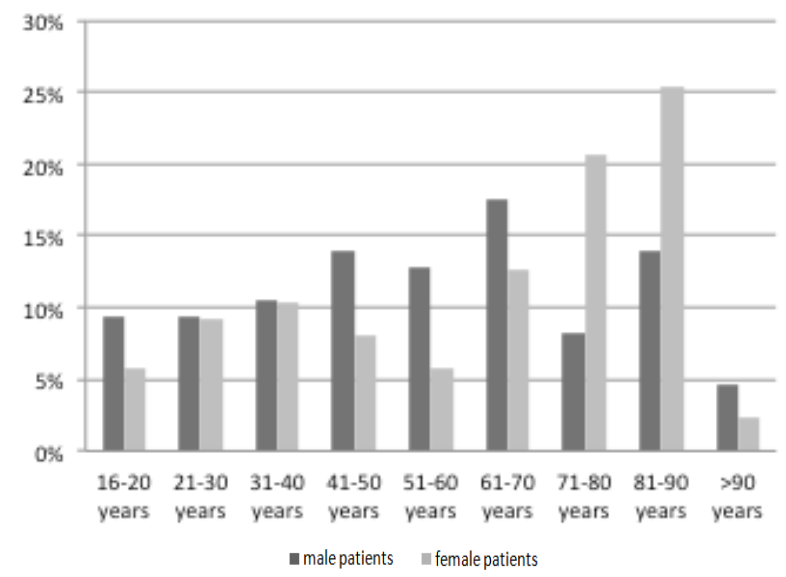

Fig. 3. Age groups of passengers hospitalized due to injuries on escalators [3]

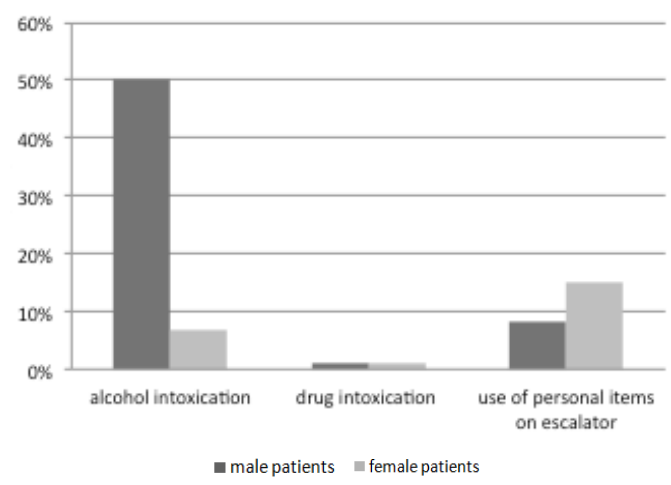

Fig. 4. Distribution of risk factors associated with accidents on escalators [3]

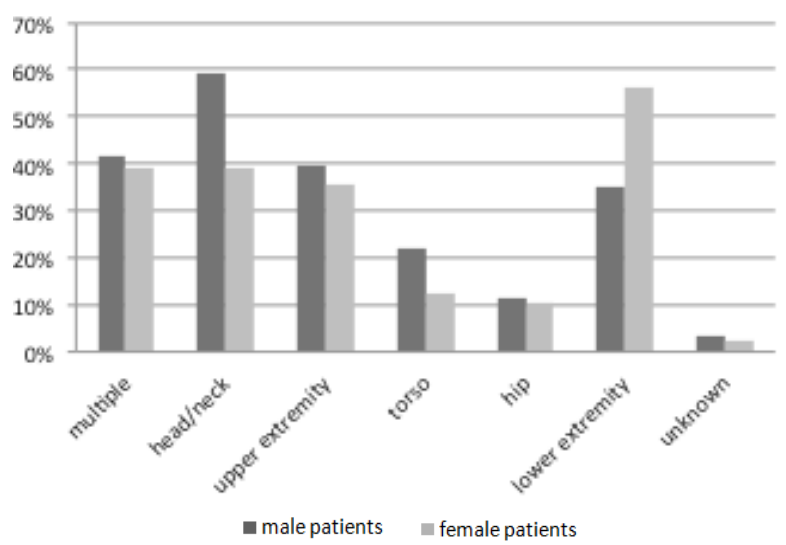

Fig. 5. Injured body parts in men and women due to accidents on escalators [3]

\section{DANGERS AND SAFETY MEASURES FOR ESCALATORS}

Domestic standards that define the area related to safety and health at work on escalators are as follows:

- $\quad$ SRPS EN 115-1:2017 - Safety of escalators and moving walks, Part 1: Construction and installation;

- $\quad$ SRPS EN 115-2:2011 - Safety of escalators and moving walks, Part 2: Rules for the improvement of safety of existing escalators and moving walks;

- SRPS CEN/TR 115-3:2018 - Safety of escalators and moving walks, Part 3: Correlation between EN 115-1:2008+A1:2010 and EN 115-1:2017;

- $\quad$ SRPS CEN/TS 115-4:2017 - Safety of escalators and moving walks, Part 4: Interpretations related to EN 115 family of standards.

The methodology of periodic checks and controls for escalators is defined by the Rulebook on technical standards for escalators and mobile paths for the transport of persons "Official Gazette of the FRJ", no. 83/94, and it is described in more detail by the standard BS 2655-7:1970 - Specification for lifts, escalators, passenger conveyors and paternosters - Testing and inspection.

The potential dangers when using escalators, and the applied safety and health measures at work will be pointed out below.

Escalators sometimes include a fire protection system, including an automatic fire detector and a dust suppression system. To limit the danger of overheating the places where the drive group is located, they generally contain additional ventilation. 
Smaller automatic and targeted cooling systems are sometimes installed in these parts of escalators. Fire protection is also sometimes achieved by adding automatic sprinklers [4].To get the best possible effect of transport by escalators, there must be free, wide surfaces at its entrance and exit. In the reduced entrance-exit space, the flow of passengers can be congested and then the effect of transport decreases. At the entrance and exit zones of escalators, there must be no obstacles that would interfere with the entry or exit of passengers from the stairs. The width of the entrance and exit zones of the escalator must be equal to the distance of the handrail axes increased by $200 \mathrm{~mm}$, Figure $6 \mathrm{a}$. The length of the input-output zone must be equal to twice the distance between the axes of the handrail.

On balustrades at the height of more than 900 $\mathrm{mm}$, additional reinforcements must be placed to prevent potential penetration and dropout of passengers, Figure 6b. If escalators are placed in pairs, with one being used for transport upwards and the other downwards, the maximum distance between adjacent balustrades must not exceed $100 \mathrm{~mm}$. If this is not possible, a safety panel must be installed, Figure 6c.

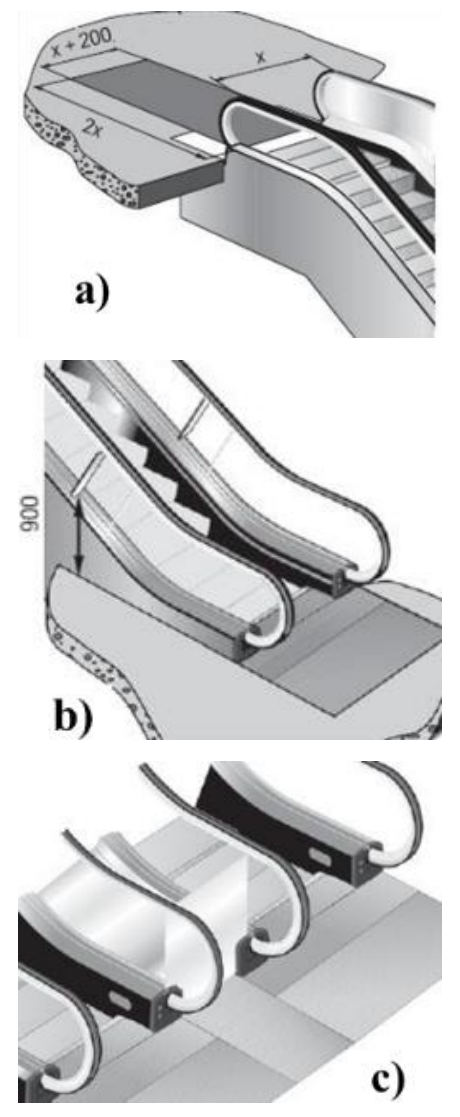

Fig. 6. Dimensions of the entrance-exit zone (a), balustrade reinforcement (b) and safety panel (c)
To protect the feet of passengers, edge brushes are placed on the sides in the lower zone of the balustrade, Figure 7a, which is defined in [5] article 5.5.3. Figure $7 \mathrm{~b}$ shows the minimum required vertical distance of the upper surface of the steps from the stationary object, which must be greater than $2134 \mathrm{~mm}$ along the entire route. For safe transport, the illumination of escalators in any part must not be less than 50 lux, according to [5] article 5.8.4.
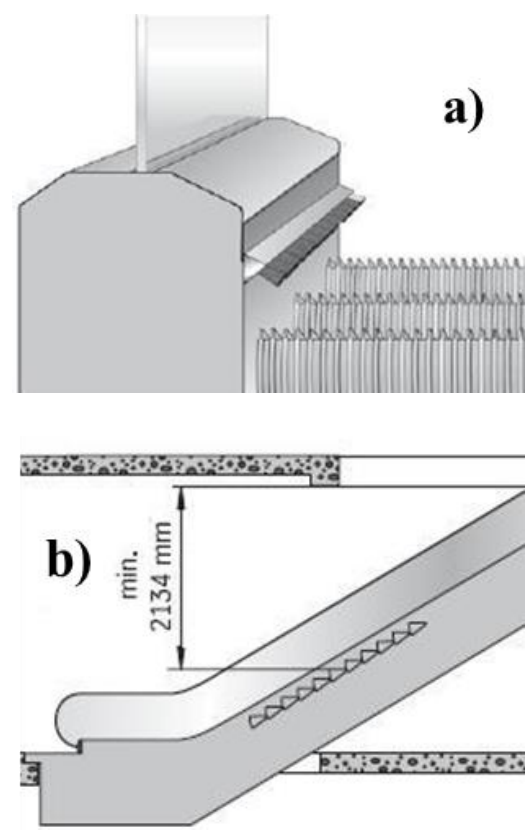

Fig. 7. Edge brushes (a) and minimum vertical distance of the stair surface from obstacles (b)

One (service) brake is provided for escalators with a lift height of less than $6 \mathrm{~m}$. For heights over $6 \mathrm{~m}$, an additional (safety brake) must be installed. In the case of a chain drive, the use of a mechanical device to prevent the downward movement of the steps when breaking the drive chain in the form of a locust on the drive sprocket or a wedge stop on the drive chain is mandatory. The service and safety brakes are usually two-pedal brakes with a suitable coupling between the motor and the gearbox as the brake drum. It is especially important to be able to regulate the braking torque in a wider range in order to adjust the braking mode, i.e. the maximum decelerations that are defined are prescribed via stopping paths. Thus in [5] article 5.4.2.6, braking distances are defined in the event of an unexpected stop on the escalator, to prevent falls of passengers on the steps at the time of stopping.

According to [5] articles 5.3.1. and 5.7.1 in order to prevent passengers from tripping and falling when entering/exiting stairs, it is necessary to install 
tread surfaces in those areas which provide safe protection and which are designed in accordance with working conditions and environmental conditions.

The gaps between two consecutive steps shall not exceed $6 \mathrm{~mm}$ in any working position, measured from the bottom of the tread surface, [5] article 5.3.4. The gaps between the steps with straight and oblique parts of steps must not exceed $5 \mathrm{~mm}$ in any position measured from the bottom of the tread surface. In the area of curves of escalators, it is allowed to increase this gap to $8 \mathrm{~mm}$.

The lack of a single step should be detected, and the escalator stopped, before the gap created by the missing step comes out of the combs. This is achieved by installing a device for monitoring missing steps at the upper and lower station, which is defined in [5] article 5.3.5.

In places where passengers can come into contact with the outer surface of the handrail, which could cause a fall from the top of the escalator, i.e. a fall over the balustrade, appropriate preventive measures should be taken, [5] article 5.13.1.6. Thus, it is envisaged to prohibit access to the dangerous place by placing permanent barriers or to increase the height of the surrounding building structure on the balustrade around the dangerous place at least $100 \mathrm{~mm}$ above the level of the handrail.

Climbing the outside of the balustrade can lead to serious injuries. Preventive measures should discourage passengers from climbing outside the balustrade, if there is a risk of falling from them, [5] article 5.5.2.3.

The distance between the handrails (Figure 8), and the profiles of their guides mounted on the balustrades should be such as to reduce the possibility of access and jamming of the passenger's fingers.

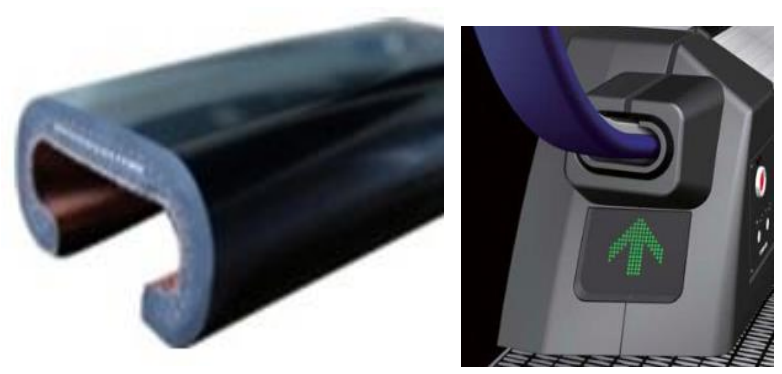

Fig. 8. Handrails

According to [5] article 5.6.2, the distance between the handrails and the profiles of their guides must not exceed $8 \mathrm{~mm}$. If there is no protection on the initial parts of the handle, the fingers can get stuck in that space, which leads to injury if the movement of the handle does not stop at the same moment. It is necessary to install appropriate protection and electrical safety devices on the initial parts of the handle, in order to prevent the interference of fingers and hands in that space, [5] article 5.6.3.1.

The insufficient connection between the combs and the tread surface of the steps at the exit areas of the escalator can lead to jams. Combs should be designed so that if an object or part of the body gets stuck, it causes it to be rejected and stopped immediately, [5] articles 5.7.2. and 5.7.3.

This phenomenon most often occurs as a consequence of subsidence, i.e. damage to the tread of the steps, where it is planned to install an appropriate safety device that will detect the disturbance and stop the escalator, [5] article 5.7.4.

On escalators, it is necessary to provide switches for emergency stopping of movement (Figure 9), where they need to be placed in visible and accessible positions, [5] article 5.12.1.
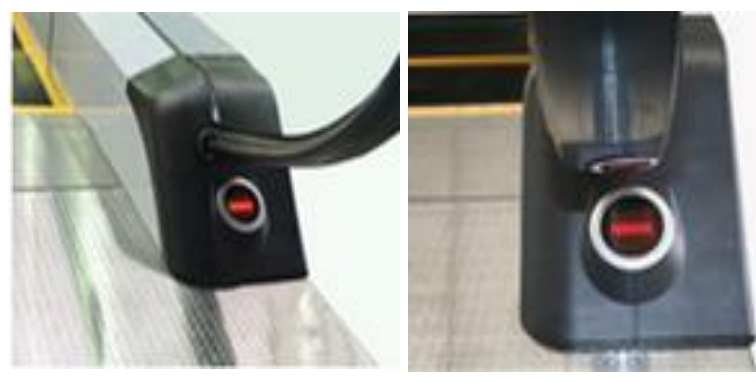

Fig. 9. Emergency stop switch

Construction obstacles such as walls, pillars, crossings of access at zigzag escalators, can cause injuries. In these places, it is necessary to take appropriate safety measures, which include the installation of deflectors.

The space between the outer edge of the handrail and the wall or other obstacle, under no circumstances should be less than $80 \mathrm{~mm}$ horizontally and $25 \mathrm{~mm}$ vertically, measured from the lower edge of the handrail, [5] article 5.13.1.2.

\section{CONCLUSION}

From all the above, it can be concluded that escalators are extremely complex mechanisms that are very widespread throughout the world. They facilitate the transport of people and enable easier and 
safer movement in busy places. However, if escalators are not functioning properly or are not used correctly, they can become a source of danger with serious consequences for passengers who use them. Dangers can arise if escalators have not been made and installed in accordance with the prescribed laws and regulations, but the cause of injuries can also be the passengers themselves, if they use them in an improper and unauthorized manner. Therefore, it is necessary to equip escalators with safety elements and devices, which are listed in this paper, which increases the safety of passengers while transporting, and reduces the level of risk and the possibility of injury to a minimum.

\section{REFERENCES}

[1] Živanić, D.: Neprekidni $i$ automatizovani transport (script), Faculty of Technical Sciences, Novi Sad, 2020.

[2] Živanić, D., Gajić, A., Đokić, R., Zelić, A.: Escalators and moving walks safety, The 5th International Conference "Towards a Humane City", Urban Transport 2030 - Mastering Change, pp. 209-214, 2015.

[3] Schminke, L. H., Jeger, V., Evangelopoulos, D. S., Zimmerman, H., Exadaktylos, A.: Western Journal of Emergency Medicine, https://bit.ly/3kctmtV, accessed on 22 . 02. 2021.

[4] National Elevator Industry, Inc.: www.neii.org, accessed on 15. 11. 2020.

[5] Standard: Safety of Escalators and Moving Walks, Part 2: Rules for the improvement of safety of existing escalators and moving walks, Standard EN 115-2 (2011). 